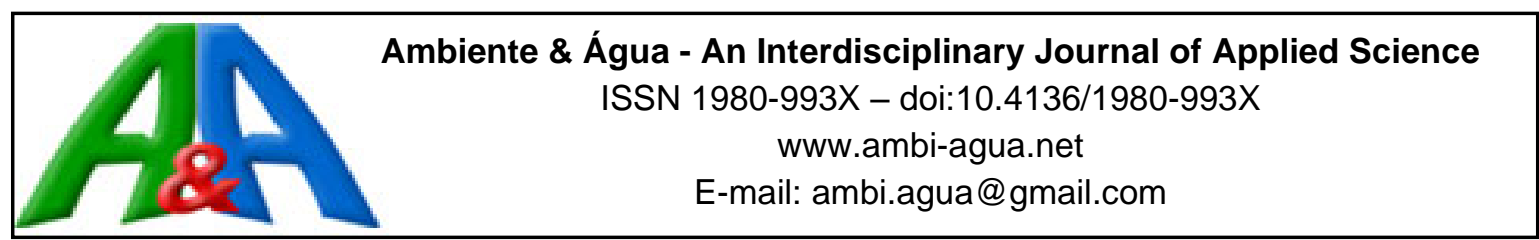

\title{
Performance of sewage treatment plant with septic tank, anaerobic filter and constructed wetland with Typha spp
}

\author{
doi:10.4136/ambi-agua.2305
}

Received: 11 Nov. 2019; Accepted: 05 Dec. 2019

\section{Paulo Fortes Neto ${ }^{1 *}$; Nara Lucia Perondi Fortes ${ }^{1}$; Elizabeth da Costa Neves Fernandes de Almeida Duarte ${ }^{2}$; Rita do Amaral Fragoso ${ }^{2}$; Ana Catarina Marcos Henriques²; Sofia Helena Lewis Lopes²; Luiza Fernanda dos Santos Pereira ${ }^{1}$}

\author{
${ }^{1}$ Departamento de Ciências Agrárias. Universidade de Taubaté (UNITAU), Est. Mun. Dr. José Luiz Cembranelli, \\ $\mathrm{n}^{\circ}$ 5000, CEP: 12081-010, Taubaté, SP, Brazil. \\ E-mail: narapfortes@gmail.com, luiza.pereira@taubate.sp.gov.br \\ ${ }^{2}$ Instituto Superior de Agronomia (ISA). Universidade de Lisboa (ULISBOA), Lisboa, Portugal. \\ E-mail: eduarte@isa.ulisboa.pt, ritafragoso@isa.ulisboa.pt, anac.henriques@gmail.com, \\ sofialewisl@outlook.com \\ *Corresponding author. E-mail: paulo.fortes@unitau.com.br
}

\begin{abstract}
The study reports the performance of a sanitary effluent treatment constituted by a septic tank, anaerobic filter and constructed wetland. The study monitored nutrient's, carbonaceous material's and thermotolerant coliform's (CT) removal efficiency during 12 months. The treatment system included a septic tank, an anaerobic filter and a horizontal subsurface flow constructed wetland cultivated with Typha spp. Effluent samples were monthly collected before and after the septic tank, anaerobic filter and wetland. The removal efficiency for $\mathrm{N}^{-\mathrm{NH}^{+}}{ }_{4}$ was $37.6 \%, 66.3 \%$ for total P, $37 \%$ for COD, $54 \%$ for BOD and $99.4 \%$ for CT. The anaerobic filter and wetland were more efficient than the septic tank. P-total reduction was higher in the constructed wetland than in the anaerobic filter. Climatic conditions influenced the evaluated constituent's removal being the highest values during hot months.
\end{abstract}

Keywords: constructed wetland, macrophytes, nutrient removal.

\section{Desempenho do tratamento de esgoto com tanque séptico, filtro anaeróbico e wetland construído com Typha spp}

\section{RESUMO}

O objetivo desta pesquisa foi avaliar o desempenho do tratamento do esgoto sanitário, no que se refere à remoção de nutrientes, material carbonáceo e coliformes termotolerantes, durante 12 meses de monitoramento. O sistema de tratamento era composto por um tanque séptico, filtro anaeróbio e wetland construído com escoamento horizontal subsuperficial cultivado com Typha spp. As amostras do efluente foram coletadas mensalmente antes e após passar pelo tanque séptico, filtro anaeróbio e wetland. A partir das análises realizadas, notouse que a eficiência do sistema na remoção para N-NH+4 foi de 37,6\%; 66,3\% para P-total; 37\% para DQO; $54 \%$ para DBO e $99,4 \%$ para coliformes termotolerante. Em relação ao desempenho das fases, foi constatado que o filtro anaeróbio e o leito cultivado foram mais eficientes na 
redução do que o tanque séptico. A redução de P-total foi mais acentuada no wetland construído do que no filtro anaeróbio. A remoção dos constituintes investigados foi influenciada pela condição climática, sendo os maiores valores observados no período de verão e os menores no período de inverno.

Palavras-chave: macrófitas, remoção de nutrientes, wetland construído.

\section{INTRODUCTION}

The system of treatment of sanitary effluents with macrophytes can be developed in a natural or artificial way. Natural systems are humid habitats, or wetlands is a term used to define large wetlands, where periodic or permanent flooding may occur. Thus, saturated soil provides an environment conducive to aquatic plants, microorganisms and animal's development (Kadlec and Wallace, 2009). The artificial systems, called constructed wetlands, are engineered systems that have been designed and constructed to mimetize the natural processes involving wetland vegetation, soils and microbial communities for wastewater treatment (Calijuri et al., 2009).

Constructed wetlands $(\mathrm{CW})$ are widely applied as a low-cost alternative or complementary system for wastewater treatment, having the advantages of low maintenance and ease of operation (Russo et al., 2019). CW can be used in primary, secondary and tertiary treatment of household, industrial and rural wastewater; groundwater and water for reuse; sludge management or runoff waters (Zhang et al., 2015). However, most of the work developed in Brazil uses CW as a secondary treatment step, used in post-treatment of decant-digester, septic tank type, compartmentalized anaerobic reactor, anaerobic sludge blanket (UASB) reactors or anaerobic ponds (Sezerino et al., 2015).

Like any other treatment process, the use of plants in the wetland is intended to reduce contaminants levels to ranges of safe and compatible limits with respect to the protection of human health or to prevent the spread of harmful substances to the environment (Brix and Arias, 2005; Sezerino et al., 2015). Among the macrophytes, Typha spp stands out as the most used in the cultivated bed, followed by Eleochanis spp and Zizaniopsis spp (Sezerino et al., 2015).

The wetland's efficiency for wastewater treatment is variable and depends on chemical and microbiological composition of the effluent, flow rate, time of hydraulic detention, plant species and filtering media (Machado et al., 2016; Meyer et al., 2013). Bregunce et al. (2011), used a system planted with Sagittaria montevidensis and verified that the removal of volatile suspended solids (VSS) efficiency was 63\%. On the other hand, Souza et al. (2004) and Barreto (2005), using a system planted with Thypha spp, obtained removal values of 52\% and 31\% respectively. Regarding the efficiency in organic matter removal expressed in chemical oxygen demand (COD), Brito (2005), used an elephant grass bedding system (Pennisetum purpureum), and Barreto (2005), with Typha spp, and showed a mean removal efficiency of 53\%. Ribas and Fortes Neto (2008), studying the Typha spp macrophyte in the bed, had an $89 \%$ reduction in COD. Concerning he to total phosphorus (P-total), Mazzola et al. (2005), evaluating the efficiency of Typha spp and Eleocharis spp, found a reduction in that Typha spp reduced the total $\mathrm{P}$ content by $30 \%$ and $11 \%$ respectively. According to these authors, this fact may be associated with the different free phosphorus, plant absorption, as Typha spp presented a high growth rate and biomass production (leaves and roots) during the period of analysis. In relation to the removal of nitrogen compounds, specifically reduction of ammonia $\left(\mathrm{N}-\mathrm{NH}_{4}\right)$, most of the literature effluent values for the constructed wetland, report a varied removal, between 30 and 60\% (IWA, 2000). According to Kadlec and Wallace (2009), the main mechanism of nitrogen removal in the wetland is the biochemical pathway, known as nitrification followed by denitrification. However, other removal mechanisms may contribute to the reduction of $\mathrm{N}-\mathrm{NH}_{3}$ 
$\mathrm{N}-\mathrm{NH}_{4}$, such as adsorption on the filter material, uptake and immobilization by macrophytes roots as well as dilution by pluviometric precipitation. The wide range of P-total and $\mathrm{N}-\mathrm{NH}_{3} \mathrm{~N}-$ $\mathrm{NH}_{4}{ }^{+}$removal values in the wetland concerns the plants vegetative cycle and climatic variables (Calijuri et al., 2009).

In evaluating the efficiency of the constructed wetland system, one must also take into account the removal of pathogenic microorganisms, generally indicated by the presence of thermotolerant coliforms. Regarding the removal of thermotolerant coliforms, several studies show range between $86 \%$ and $99 \%$, and these values vary according to macrophyte species. This is due to the inhibition of pathogenic microorganism's growth microorganisms by the macrophytes rhizosphere microorganisms (Brix, 1997; Ribas and Fortes Neto, 2008). The thermotolerant coliforms reduction also occurs due to the filtration mechanism, to the fixation of biofilms in the medium and the roots of macrophyte roots toxic substances and antibiotics release and predation by nematodes and parasites (Souza et al., 2004; Almeida et al., 2010).

Most of the studies carried out to assess the efficiency of the constructed wetland in nutrient removal, organic load and thermotolerant coliforms were carried out under pilot project conditions and with a short monitoring period. The present work objective was to verify the constructed wetland performance in real operational scale, in terms of nutrient (nitrogen and phosphorus), carbonaceous material and thermotolerant coliforms removal along 12 months of monitoring.

\section{MATERIALS AND METHODS}

The experiment occurred at the Sewage Treatment and Wastewater Treatment Unit of the, Agrarian Sciences Department - University of Taubaté, Taubaté (Brazil). The sewage treatment plant (STP), consisting of a septic tank followed by an upflow anaerobic filter and a sub-surface flow wetland. The septic tank and the anaerobic filter were constructed according to NBR 7229 (ABTN, 1993) and the CW cultivated bed was dimensioned according to the specifications stipulated by Philippi and Sezerino (2004).

The septic tank was constructed in a rectangular form $(5.4 \mathrm{~m}$ long, $3.5 \mathrm{~m}$ wide, $1.6 \mathrm{~m}$ high and a total volume of $30.24 \mathrm{~m}^{3}$ ) and with a 10 days hydraulic residence time (HRT). The upflow anaerobic filter was constructed in a circular format $\left(3 \mathrm{~m}\right.$ diameter, $2 \mathrm{~m}$ high and $6 \mathrm{~m}^{3}$ total volume) and 2 days HRT. The CW was built in cylindrical format ( $3 \mathrm{~m}$ in diameter, $2 \mathrm{~m}$ high and $6 \mathrm{~m}^{3}$ in total volume) with gravel as filling medium and using Typha spp with 4 plants $/ \mathrm{m}^{2}$ and constructed in one and a two HRT.

Figure 1 shows the general layout of the STP, with a flow rate of $3.0 \mathrm{~m}^{3}$ average standard deviation day ${ }^{-1}$, 14-days of HRT and four monitoring points.

The evaluation of the STP performance was carried out between April 2009 and March 2010 after wetland cultivation, with effluent samples collected three times a week, always at 9:00 am, in two collection points: P1 -influent and P4-effluent. For the evaluation of treatment stages performance, monitoring was carried out during December 2009 and effluent samples collected at four points: P1-influent, P2-septic tank effluent, P3-effluent post- anaerobic filter and P4-effluent from CW bed (Figure 1). Effluent samples were kept in sterilized glass containers under refrigeration until analysis in the Water and Effluent Laboratory of the Civil, Environmental and Sanitary Engineering Department -University of Taubaté. The analyzed variables were: ammoniacal nitrogen $\left(\mathrm{N}-\mathrm{NH}_{4}{ }^{+}\right.$), total phosphorus (P-total), chemical oxygen demand (COD), biochemical oxygen demand (BOD5) and thermotolerant coliforms (TC). Laboratory tests were performed in accordance with Standard Methods for the Examination of Water and Wastewater (APHA, 2000). Total nitrogen, total phosphorus (P-total), chemical oxygen demand (COD), biochemical oxygen demand (BOD) and thermotolerant coliforms 
(TC) results, determined in the four collection points, were submitted to descriptive statistics for average and dispersion values determination.

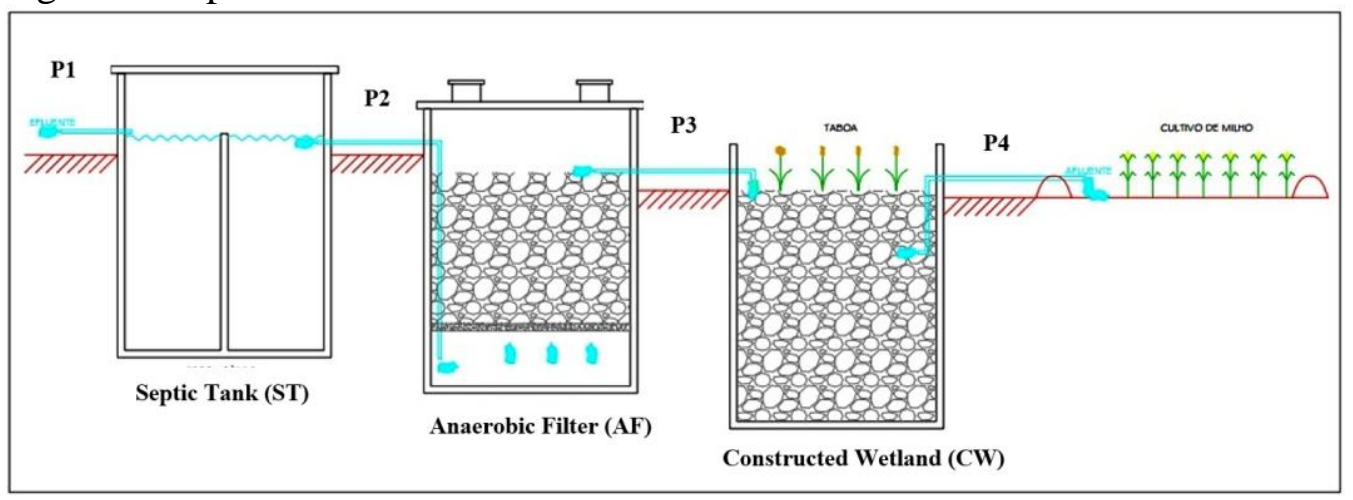

Figure 1. Sewage treatment plant (STP) components and collection points, P1 to P4 (without scale).

\section{RESULTS AND DISCUSSION}

\subsection{Sewage treatment system overall performance}

Table 1 shows the results of the effluent samples analyzed variables collected at the entrance and exit of the sewage treatment plant (P1 and P4). It is observed that the levels of $\mathrm{N}$ $\mathrm{NH}^{+}$, $\mathrm{P}$-total, $\mathrm{COD}, \mathrm{BOD}$ and thermotolerant coliforms are reduced after passing through the treatment system. Removal efficiencies were: $99.4 \%$ for thermotolerant coliforms, $66.3 \%$ for P-total and $54.0 \% \mathrm{BOD}_{5}, 37.6 \%$ for $\mathrm{N}^{-\mathrm{NH}_{4}}{ }^{+}$and $37.0 \%$ COD.

Table 1. Mean values, standard deviations and removal efficiencies during the monitoring of the sewage treatment system between April 2009 and March 2010.

\begin{tabular}{lccc}
\hline Variables & \multicolumn{2}{c}{ Collection Points } & Efficiency \\
\hline & P1 & P4 & $(\%)$ \\
\hline $\mathrm{N}^{-N_{H}}{ }_{4}\left(\mathrm{mg} \mathrm{L}^{-1}\right)$ & $49.6 \pm 4.8$ & $31.2 \pm 8.5$ & 37.6 \\
P-total $\left(\mathrm{mg} \mathrm{L}^{-1}\right)$ & $31.5 \pm 4.3$ & $10,6 \pm 3,7$ & 66.3 \\
$\mathrm{COD}\left(\mathrm{mg} \mathrm{L}^{-1}\right)$ & $139.9 \pm 15.1$ & $88.1 \pm 12.4$ & 37.0 \\
BOD $\left(\mathrm{mg} \mathrm{L}^{-1}\right)$ & $88.9 \pm 9.7$ & $40.9 \pm 11.9$ & 54.0 \\
Thermotolerant coliforms (NMP $\left.100 \mathrm{~mL}^{-1}\right)$ & $101 \pm 15.7 \times 10^{3}$ & $5.4 \pm 2.3 \times 10^{2}$ & 99.4 \\
\hline
\end{tabular}

$\mathrm{BOD}_{5}$ mean removal values, P-total and thermotolerant coliforms were within the range considered adequate for sewage treatment with septic tank followed by sand filter, and the removal of $\mathrm{N}_{-} \mathrm{NH}_{4}{ }^{+}$was within the range expected for the septic tank treatment in conjunction with aerobic filter. On the other hand, the COD result was below the minimum limit established for all forms of treatment used after the effluent passes through the septic tank (ABNT, 1997). Comparing the results with those from the literature, for $\mathrm{N}_{-} \mathrm{NH}_{4}{ }^{+}$removal, values were within the 33\% and 38.6\% range (Olijnyk, 2007; Assumpção et al., 2011; Mazzola et al., 2005) and below 78\% upper limit (Avelar, 2009). The COD and the $\mathrm{BOD}_{5}$ were below the $57 \%$ to $98 \%$ and $61 \%$ to $97 \%$ range, respectively (Sezerino, 2006; Olijnyk 2007; Roche et al., 2008). In addition, the thermotolerant coliforms were in the range of 90 to $99.9 \%$ (Calijuri et al., 2009). This wide range of removal values found in the literature relates to different conditions in which the studies were carried out, such as: effluent composition; effluent flow, hydraulic residence time and monitoring period; (Almeida et al., 2010, Assumpção et al., 2011).

Figure 2, the removal efficiency of $\mathrm{N}^{-\mathrm{NH}^{+}}{ }_{4}$, P-total, COD, BOD and thermotolerant coliforms observed during the monitoring period between April 2009 and March 2010 is shown. It is noted that efficiency of thermotolerant coliforms remains constant and above $90 \%$ during 
the whole monitoring period, followed by the total P-upward trend with few oscillations in the removal, with values always above $50 \%$.

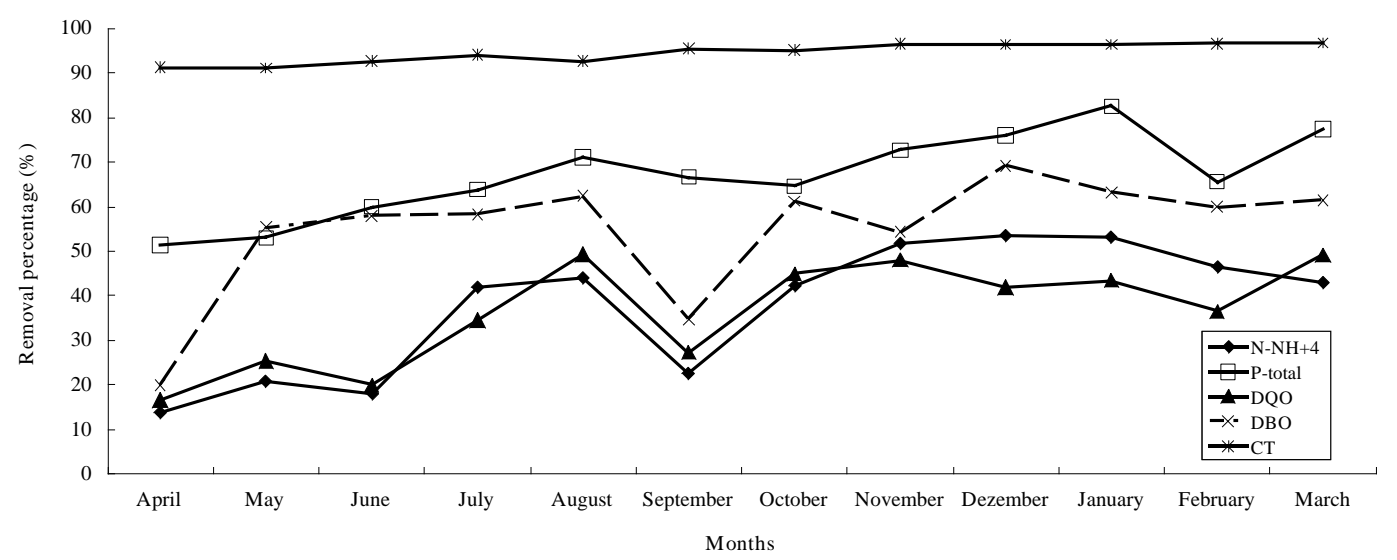

Figure 2. Variation of ${\mathrm{N}-\mathrm{NH}_{4}}^{+}$, P-total, $\mathrm{COD}, \mathrm{BOD}$ and thermotolerant coliforms (TC) in effluent samples collected after passing through the $\mathrm{CW}$ bed during the months of April 2009 to March 2010.

On the other hand, the behavior profile of COD, $\mathrm{BOD}_{5}$ and $\mathrm{N}-\mathrm{NH}_{4}{ }^{+}$was similar with a sharp removal decrease in September 2009. Afterwards, there was an increase of removal values, to values, higher than those determined between April and September 2009.

The trend representing the removal of COD, $\mathrm{BOD}_{5}$ and $\mathrm{N}^{-\mathrm{NH}_{4}}{ }^{+}$(Figure 2 ) suggests that something occurred in September 2009 effluent that inhibited microorganisms activity in the treatment system, since the variables relate to the process of biodegradation of the organic fractions present in sanitary sewage (Kadlec and Brix, 1995).

In general, with the exception in September, there were no significant fluctuations observed with the cycles of fall and yield gain in the ${\mathrm{N}-\mathrm{NH}_{4}+}^{+}$, P-total, COD, $\mathrm{BOD}_{5}$ and thermotolerant coliforms (TC), probably because the treatment was still in the second year of operation. In this regard, some authors report that the removal efficiency of nutrients, organic matter and thermotolerant coliforms tends to be higher at the beginning of the process but reduces with the operation time of the sewage treatment system (Souza et al., 2004; Calijuri et al., 2009).

The temperature may have been another important factor that influenced the $\mathrm{N}^{-\mathrm{NH}_{4}}{ }^{+}, \mathrm{P}-$ total, $\mathrm{COD}, \mathrm{BOD}_{5}$ and TC thermotolerant coliforms removal. When analyzing the relationship between the periods of cold months (April to September/2009) with hot months (October/2009 to March/2010) in terms of efficiency in the reduction, it is noticed that the removal rate of the variables analyzed were influenced by the conditions related to temperature (Figure 3 ). The removal values were higher in the warm months than in the cold months, and the variables $\mathrm{N}$ $\mathrm{NH}_{4}, \mathrm{COD}, \mathrm{BOD}_{5}$ and P-total were more sensitive to climatic variation than thermotolerant coliforms.

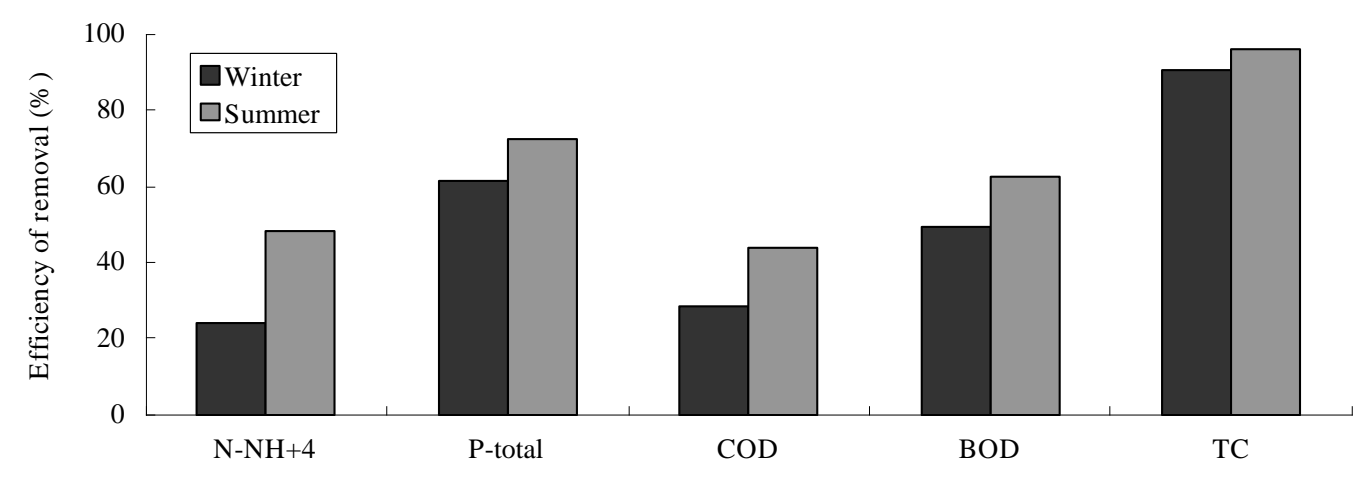

Rev. Ambient. Água vol. 7 (supplement) - Taubaté 2019 
Figure 3. Efficiency of $\mathrm{N}^{-\mathrm{NH}_{4}}{ }^{+}, \mathrm{P}$-total, $\mathrm{COD}, \mathrm{BOD}_{5}$ and thermotolerant coliforms (TC) removal in effluent samples collected during periods of cold and hot months between April 2009 and April 2010.

\subsection{Phases performance of the phases of the sewage treatment system}

Calijuri et al. (2009) treated effluent samples from an upflow anaerobic reactor system with CW with Typha spp. and showed that for the total $\mathrm{P}$ and total coliform the removal efficiency was higher in the warmer months than in the colder months. In this respect, Andrade (2012), evaluating the performance of Canna generalis in the treatment of sewage, found that temperature could accelerate or delay the plants development and microorganisms and, consequently, influence process efficiency. Bahgat et al. (1999) state that, in wetland cultivated systems, the biological activity is directly influenced by the ambient temperature, which, when elevated, can increase the microbial activity in nutrient removal and organic load of the effluent.

Figure 4 shows the efficiency of $\mathrm{N}^{-\mathrm{NH}_{4}}{ }^{+}$, P-total, COD, BOD and thermotolerant coliforms removal by each treatment phase. The lowest removal values for all the variables were found in the effluent after passing the septic tank. Subsequently, the removal efficiency increases in the anaerobic filter and $\mathrm{CW}$. The high capacity of nutrient removal, organic load and pathogenic microorganisms determined in the wetland cultivated confirm the hypothesis of its use in the post-treatment of anaerobic effluents (Brito et al., 2005; Avelar et al., 2009; Sezerino et al., 2015).

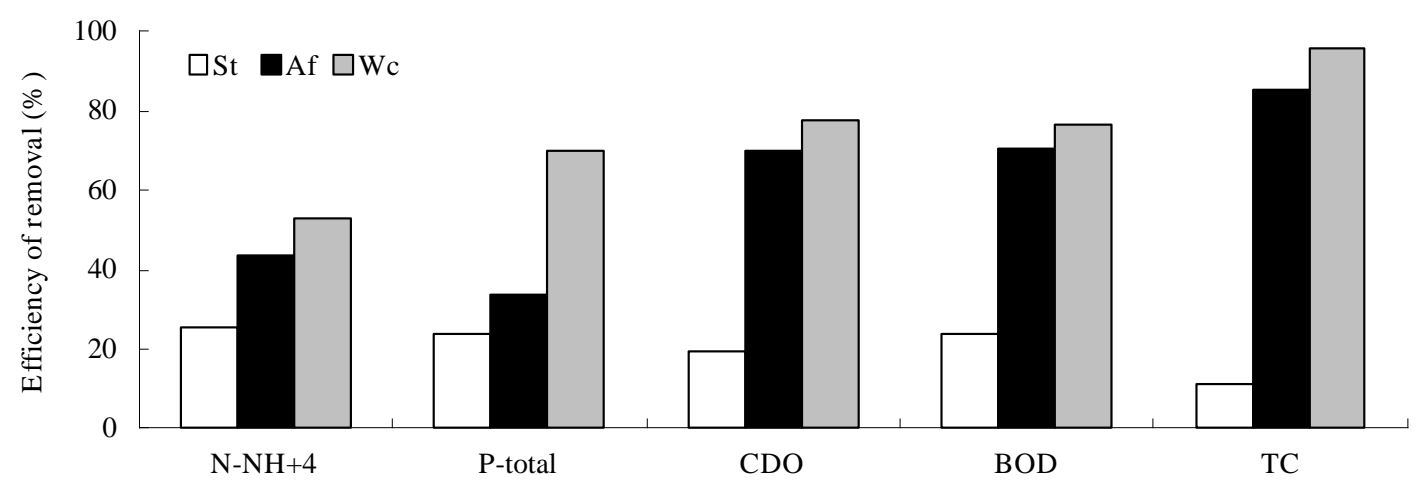

Figure 4. Phases Performance of treatment system in the removal of $\mathrm{N}-\mathrm{NH}_{4}{ }^{+}, \mathrm{P}$-total, $\mathrm{COD}$, $\mathrm{BOD}_{5}$ and thermotolerant coliforms (TC) determined in samples collected before and after the septic tank (St), anaerobic filter (Af) and constructed wetland (Wc).

Removal of $\mathrm{N}^{-\mathrm{NH}_{4}}{ }^{+}$in the septic tank was $25.7 \%$. This value was within the mean verified by other authors who found reductions varying between $3 \%$ and $39 \%$ (Oliveira and Von Sperling, 2005; Luna et al., 2013). The mean percentage of COD removal and BOD 5 in the septic tank was $19.6 \%$ and $23.9 \%$, respectively. These values are below the observed in other studies with an average removal ranging from 30\% to 55\%. Thus, Colares \& Sandri (2013), analyzing the efficiency of sewage treatment with septic tank followed by $\mathrm{CW}$ bed, found an efficiency of $23.58 \%$ for COD and $42.34 \%$ for BOD. Jordão and Pessoa (2011) observed a 35\% to $65 \%$ removal in the BOD values of septic tank effluent; and Borges (2008) verified an average $52 \%$ removal in single-chamber septic tank effluent. The efficiency of the $\mathrm{N}^{-\mathrm{NH}_{4}}{ }^{+}$ removal in the anaerobic filter effluent was $43.8 \%$. However, it is important to note that this high removal rate may be associated to the nitrification, immobilization and volatilization processes of $\mathrm{N}-\mathrm{NH}_{4}{ }^{+}$by the microorganisms adhered to the biofilm and to the filter media pores (Lamego and Costa, 2011).

As for the action of the anaerobic filter in the P-total removal (Figure 4), it can be stated that it was efficient, providing a removal of $34 \%$, compatible with the removal value range 
(20\% a 50\%) stipulated by ABNT (1997). According to Prochaska and Zouboulis (2003), incorporation of phosphorus into the biofilm is an important removal mechanism in anaerobic filters, due to the phosphorous participation in microorganism's metabolism and its consequent immobilization and accumulation in the microbial biomass.

The anaerobic filter showed a high COD and $\mathrm{BOD}_{5}$ removal, with mean values of $70 \%$ and $70.7 \%$ respectively, results that are within the range considered adequate for the removal of pollutants, when the septic tank is followed by the anaerobic filter (ABNT, 1997). The values are also consistent with the efficiency range observed by several authors. For example, Calijuri et al. (2009) found values of COD removal ranging from $69 \%$ to $75 \%$, and $\mathrm{BOD}_{5}$ between $77 \%$ and $84 \%$ (TDH $=7$ hours). Tonetti et al. (2010) found an average removal of $76 \pm 12 \% \mathrm{COD}$ and $71 \pm 15 \%$ BOD (TDH $=9$ hours). The high efficiency in the removal of COD and BOD 5 in the anaerobic filter can be associated to the HRT, which in this case was 48 hours, well above the recommended 12 hours by NBR 7.229 (1993).

Regarding the thermotolerant coliforms removal, there was an expressive reduction of $85.2 \%$, when compared to the $11.1 \%$ verified in the septic tank. This value of is similar to that observed by Cavalcante et al. (2010) that, studying the anaerobic filter sanitary efficiency, found a removal of $83.4 \%$. Pereira-Ramirez et al. (2004), using an anaerobic filter in the posttreatment of an anaerobic flow reactor, determined thermotolerant coliform's removal ranging from $80 \%$ to $96 \%$.

The $\mathrm{N}-\mathrm{NH}_{4}{ }^{+}$removal, after the $\mathrm{CW}$, was $52.9 \%$. This value was higher than that observed in the septic tank and in the anaerobic filter (Figure 4). The high removal of $\mathrm{N}_{-} \mathrm{NH}_{4}{ }^{+}$, after the $\mathrm{CW}$ bed, occurs due to the nitrification and immobilization processes of ammonia carried out by the microorganisms in the rhizosphere of Typha spp, and also by the plant absorption, which roots are adhered to the filter medium used to fill the cultivated bed (IWA, 2000; Olijnyk et al., 2007). The ${\mathrm{N}-\mathrm{NH}_{4}}^{+}$removal observed in the present study for the $\mathrm{CW}$ bed is in accordance with reference values observed by several authors in effluent samples treated in bed systems with different species of macrophytes (Souza et al., 2004; Brasil et al., 2005; Avelar, 2009).

The cultivated bed was more efficient in the P-total removal when compared to the septic tank and anaerobic filter, with a value of $69.8 \%$ (Figure 4). This value was above literature values observed by Mazzola et al. (2005) and Assumpção et al. (2011) in domestic effluent samples treated in a Typha spp CW bed. These authors verified that the average efficiency for the P-total removal ranged from $20 \%$ to $25.6 \%$. On the other hand, it was below the value reported by Avelar (2009), who evaluated a CW filled with steel slag using Typha spp. for Ptotal removal efficiency and found a 78\% removal. Also Campos et al. (2002) reported a 95\% phosphorus removal in treated slurry samples in CW with Typha spp.

These results suggest that the efficiency of P-total removal is associated with HRT, effluent flow rate, filter medium type of material, macrophyte species and development, adsorption in plant and microbiological biomass, precipitation of insoluble compounds and adsorption to the substrate (Campos et al., 2002; Mazzola et al., 2005; Avelar, 2009; Assumpção et al., 2011).

The COD reduction was higher $(77.8 \%)$ in the $\mathrm{CW}$ bed than in the other phases of the treatment process (Figure 4). The results were within the values verified by other authors who found, in similar studies, COD removals varying between $60 \%$ and $90 \%$ (e.g. Silva et al., 2004). The percentage of $\mathrm{BOD}_{5}$ removal from the cultivated bed effluent was $76.4 \%$ (Figure 4). This result is below the values of $85 \%$ and $90.7 \%$ already observed by other authors under different conditions, such as HRT, macrophyte species and type of filter medium (Duarte, 2008; Avelar, 2009; Almeida et al., 2010). The reduction of COD and $\mathrm{BOD}_{5}$ observed in the effluent, after the CW, may be associated with the presence of Typha spp, as Brix (1997) and Brix and Arias (2005) and transfer it to the rhizomes and roots through the aerenchyma, making the region of the rhizosphere that is located inside the filter medium aerobic. The oxygen transfer to the bed layer, located below the water sheet, increases the degradation of organic compounds by the 
microorganisms that inhabit the Typha spp rhizosphere (Brix, 1997). The removal of suspended organic matter, sedimentable or soluble in the $\mathrm{CW}$ bed also occurs through physical processes, such as sedimentation, due to the low flow rate and filtration, the presence of roots, rhizomes and the gravel used as a filter medium (USEPA, 1988).

Figure 4, shows the thermotolerant coliforms reduction in the effluent after the septic tank, anaerobic filter and CW bed. The CW had a $95.7 \%$ pathogenic microorganism's removal. This value is within the ones verified by several authors that used CW system for sanitary effluents treatment (Avelar, 2009; Calijuri et al., 2009; Almeida et al., 2010; Bregunce et al., 2011).

According to the study published by IWA (2000), the reduction of pathogenic microorganisms, in a system that includes $\mathrm{CW}$ in the final phase of treatment, occurs by the appropriate combination of physical, chemical and biological factors. For physical factors, filtration, exposure to UV and sedimentation are reported, concerning chemical reactions pathways factors, oxidation, exposure to biocides excreted by macrophytes roots and adsorption along organic fractions in the filter medium and in the rhizosphere are mentioned. In relation to the mechanisms of biological removal, the following are described: predation by nematodes and protozoa, attack by bacteria and viruses, and finally natural death (Sousa et al., 2004; Brasil, et al., 2005; Almeida et al., 2010).

\section{CONCLUSIONS}

The sewage treatment system with septic tank, anaerobic filter and CW showed a high efficiency in the removal of thermotolerant coliforms (99.4\%) and total $\mathrm{P}(66.3 \%)$, medium for $\mathrm{BOD}_{5}(54.0 \%)$, and low for $\mathrm{N}-\mathrm{NH}_{4}{ }^{+}(37.6 \%)$ and $\mathrm{COD}(37.0 \%)$.

The temperature influenced the sewage treatment performance in the reduction of $\mathrm{N}_{-} \mathrm{NH}_{4}{ }^{+}$, P-total, COD, BOD 5 and thermotolerant coliforms.

The lowest removal values for $\mathrm{N}-\mathrm{NH}_{4}{ }^{+}$, P-total, $\mathrm{COD}, \mathrm{BOD}$ and thermotolerant coliforms were in the septic tank and the highest in the anaerobic filter and $\mathrm{CW}$.

The P-total removal was higher in the constructed wetland due to the phosphorus absorption by t Typha spp roots.

\section{ACKNOWLEDGMENT}

To the CNPq, for the funding (Universal Announcement 2008 Process No 27/2008).

\section{REFERENCES}

ALMEIDA, R.A.; PITALUGA, D.P.S.; REIS, R. P. A. Tratamento de esgoto doméstico por zona de raízes precedida de tanque séptico. Revista Biociências, v. 16, n. 1. 2010.

AMERICAN PUBLIC HEALTH ASSOCIATION (APHA). (2000). Standard methods for the examination of water and wastewater. 20. ed. Washington: APHA. AWWA. WEF.

ANDRADE, H.H.B. Avaliação do desempenho de sistemas de zona de raízes (wetlands construídas) em escala piloto aplicados ao tratamento de efluente sintético, 2012, 100f. Dissertação (Mestrado em Engenharia Civil), Programa de Pós-Graduação em Engenharia Civil, Universidade Tecnológica Federal do Paraná. Curitiba. 2012.

ASSOCIAÃO BRASILEIRA DE NORMAS TÉCNICAS - ABNT. NBR 7229: construção e instalação de fossas sépticas e disposição dos efluentes finais. Rio de Janeiro, 1993. $18 \mathrm{p}$.

Rev. Ambient. Água vol. 7 (supplement) - Taubaté 2019 
ASSOCIAÇÃO BRASILEIRA DE NORMAS TÉCNICAS (ABNT). NBR13.969 - Tanques sépticos - Unidades de tratamento complementar e disposição final dos efluentes líquidos - Projeto, construção e operação. Rio de Janeiro: ABNT, 1997.

ASSUMPÇÃO, J. G.; UENO, M.; FORTES NETO, P.; ROSA, L. C. L. Desempenho do leito cultivado, de uma estação de tratamento de efluentes gerado em uma instituição de ensino, após período de inatividade. Revista Ambiente \& Água, v. 6, n. 3, p. 165-178, 2011.

AVELAR, J.C.; CASSINI, P.S.; VIEIRA, A.B.; GONÇALVES, R.F. Avaliação do tratamento de efluentes domésticos utilizando escória de aciaria LD como meio suporte em leitos cultivados e não-cultivados. In: $25^{\circ}$ Congresso Brasileiro de Engenharia Sanitária e Ambiental, 20-25 Set. 2009, Recife. Proceedings[...] Recife: ABES. 1 CD-ROM.

BAHGAT, M., DEWEDAR A. E ZAYED A. Sand filter used for wastewater treatment: buildup and distribution of microorganisms. Water Research, v.33, n.8, p.1949-1955, 1999.

BARRETO, C. O. (2005). Eficiência de leito de macrófitas como unidade de polimento de efluente de indústria de aditivos para ração, 2005, 53F. Dissertação (Mestrado em Engenharia Agrícola) - Faculdade de Engenharia Agrícola. Universidade Estadual de Campinas, Campinas. 2005.

BORGES, A.C.; MATOS, A.T.; CALIJURI, M.C.; OLIEIRA, G.H.H.; ROLDÃO, J.S.F. Uso de traçadores para avaliação da hidrodinâmica de sistemas alagados construídos operando sob clima tropical. Engenharia Agrícola, v. 29, n. 2, p. 301-310, 2009.

BRASIL, M. S.; MATOS, A. T.; SOARES, A. A., FERREIRA, P. A. Qualidade do efluente de sistemas alagados construídos, utilizados no sistema de tratamento de esgoto doméstico. Revista Brasileira de Engenharia Agrícola e Ambiental, v. 9, p. 133-137, 2005.

BRITO, L.P.; ANDRADE NETO, C.O.; LUCAS FILHO, M.; SILVA, D.A.; LIMA, A.D. 2005. Estudo comparativo da eficiência de um wetland e um filtro biológico anaeróbio na remoção de sólidos suspensos, DBO e DQO. In: 23 Congresso Brasileiro de Engenharia Sanitária e Ambiental, 18-23 Set., Campo Grande. Proceedings[...] Campo Grande: ABES, 2005. 1 CD-ROM.

BRIX, H. Do macrophytes play a role in constructed treatment wetlands. Water Science \& Technologic, v. 35, n. 5, p.11-17, 1999.

BRIX, H.; ARIAS, C. A. The use of vertical flow constricted wetlands for on-site treatment of domestic wasterwater. New Danish guidelines. ELSEVIER. Ecological Engineering, v. 25, n. 5, p. 491-500, 2005.

BREGUNCE, D.T.; VEIGA, V. B.; MARANHO, L.T.; CUBAS, S.A. Avaliação de sistema de leito cultivado com a macrófita Sagittaria montevidensis Cham. \& Schltdl. para tratamento de águas urbanas poluídas. Revista Brasileira de Biociências, v. 9, n. 1, p. 86-95, 2011.

CAVAlCANTE, F. L., ANDRADE NETO, C. O., MELO, H. N. S. Eficiência sanitária de filtros anaeróbios avaliada em função da remoção de ovos de vermes e coliformes fecais. Revista AIDIS. v. 3, n. 1, p. 49-61, 2010.

CALIJURI, M. L.; BASTOS, R. K. X.; MAGALHÃES, T. B.; CAPELETE, B. C.; DIAS, H. O. Tratamento de esgotos sanitários em sistemas reatores UASB/wetlands construídas de fluxo horizontal: eficiência e estabilidade de remoção de matéria orgânica, sólidos, 
nutrientes e coliformes. Engenharia Sanitária e Ambiental, v. 14, n. 3, p. 421-430, 2009.

COLARES, C.J.G.; SANDRI, D. Eficiência do tratamento de esgoto com tanques séptico seguidos de leitos cultivados com diferentes meio suporte. Revista Ambiente \& Água. v. 8, n. 1, p. 172-185, 2013.

CAMPOS, J. C.; FERREIRA, J. A.; MANNARINO, C. F.; SILVA, H. R.; BORBA, S. M. P. (2002). Tratamento do chorume do aterro sanitário de Piraí (RJ) utilizando wetland. In: 6 Simpósio Ítalo Brasileiro de Engenharia Sanitária e Ambiental, 1-5 Set., Vitória, Proceedings[...] Vitória: ABES, 2002. 1 CD-ROM.

DUARTE, A. S.; AIROLDI, R. P. S.; FOLEGATTI, M. V.; BOTREL, T. A.; SOARES, T. M. Efeitos da aplicação de efluente tratado no solo: $\mathrm{pH}$, matéria orgânica, fósforo e potássio. Revista Brasileira de Engenharia Agrícola e Ambiental, v. 12, p.302-310, 2008.

INTERNATIONAL WATER ASSOCIATION. (2000). Constructed Wetlands for Pollution Control: processes, performance, design and operation. Scientific and Technical. London: IWA Publishing, Report $\mathrm{N}^{\circ} .8$.

JORDÃO, E. P.; PESSÔA, C. A. (2011). Tratamento de esgotos domésticos. 6. ed. Rio de Janeiro: ABES, p. 1050.

KADLEC, R. H. \& BRIX H., (Eds). (1995). Wetland Systems in Water Pollution Control. Water Science and Technology, v. 32, n. 3, p. 1-376, 1993.

KADLEC, R. H.; WALLACE, S. D. (2009). Treatment Wetlands. 2th. Ed. Boca Raton: CRC, Taylor \& Francis Group.

KADLEC, R.H. E KNIGHT, R.L. (1996). Treatment Wetlands. Boca Raton, Florida: Lewis Publishers. p. 893.

LAMEGO NETO, L. G.; COSTA, R. H. R. Tratamento de esgoto sanitário em reator híbrido em bateladas sequenciais: eficiência e estabilidade na remoção de matéria orgânica e nutrientes (N, P). Engenharia Sanitária e Ambiental, v. 16, n. 4, p. 411-420, 2011.

LUNA, M.L.D.; SOUZA, J.T.; LIMA, V.L.A.; ALVES, A.S.; PEARSON, H.W. Póstratamento de efluente de tanque séptico utilizando filtros intermitentes de areia operando em condições tropicais. Sciencia Plena. v.9, n. 9, p. 1-8, 2013.

MACHADO A.I.; BERETTA, M.; FRAGOSO, R.; DUARTE, E. Overview of the state of the art of constructed wetlands for decentralized wastewater management in Brazil Journal of Environmental Management. v. 187, n.1, p. 560-570, 2017.

MAZZOLA, M.; ROSTON, D.M.; VALENTIM, M.A.A. Uso de leitos cultivados de fluxo vertical por batelada no pós-tratamento de efluente de reator anaeróbio compartimentado. Revista Brasileira de Engenharia Agrícola e Ambiental, v. 9, n. 2, p.276-283, 2005.

MEYER, D., MOLLE, P.; ESSER, D.; TROESCH, S.; MAIS, F.; DITTMER, V. Constructed wetlands for combined sewer overflow treatment comparasion of German, French and Italian approaches. Water, v.5, 1-12p. 2013.

OLIJNYK, D.P.; SEZERINO, P.H.; FENELON, F.R.; PANCERI, B. PHILIPPI, L.S. (2007). Sistemas de tratamento de esgoto por zona de raízes: análise comparativa de sistemas instalados no estado de Santa Catarina. In: $24^{\circ}$ Congresso Brasileiro de Engenharia 
Sanitária e Ambiental. 2-7 Set., Belo Horizonte, Proceedings[...] Belo Horizonte: ABES, 2007. 1 CD-ROM.

OLIVEIRA, S.M.A.C; VON SPERLING, M. Avaliação de 166 ETEs em operação no país, compreendendo diversas tecnologias. Parte I-Análise de desempenho. Engenharia Sanitária e Ambiental, v. 10, n. 4, p.347-357, 2005.

PHILIPPI, L.S.; SEZERINO, P.H. (2004). Aplicação de sistemas tipo wetlands no tratamento de águas residuárias: utilização de filtros plantados com macrófitas. Florianópolis: Ed. do Autor. 144 p.

PEREIRA, E. L.; CAMPOS, C. M. M.; MOTERANI, F.; OLIVEIRA, A. M. NETO. (2011). Eficiência de um sistema de reatores anaeróbios no tratamento de efluentes líquidos de suinocultura. Acta Scientiarum Technology, v. 33, n. 3, p. 287-293, 2011.

PEREIRA-RAMIREZ, O.; ANTUNES, R.M.; ORLANDO, M.S.; KOETZ, P.R.Filtro anaeróbio utilizado como pós-tratamento de um reator anaeróbio de fluxo ascendente (UASB) para dejetos de suinocultura. Revista Brasileira de Agrociência. v. 10, n.3, p. 339-346, 2004.

PROCHASKA, C. A.; ZOUBOULIS, A. I. Performance of intermittently operated sand filters: a comparable study, treating wastewater of different origins. Water, Air, and Soil Pollution, v. 147, p. 367-388, 2003.

RIBAS, T.B.C.; FORTES NETO, P. Disposição no solo de efluentes de esgoto tratado visando à redução de coliformes termotolerantes. Revista Ambiente \& Agua, v. 3, n. 3, p. 81-94, 2008.

RUSSO, N.; MARZO, A.; RANDAZZO, C.; CAGGIA, C.; TOSCANO, A.; CIRELli, C. Constructed wetlands combined witch desinfection systems for removal of urban wastewater contamination. Science of the Total Environment. V. 656, p. 558-566, 2019.

SAEED, T.; SUN, G. A review on nitrogen and organics removal mechanisms in subsurface flow construed wetlands: Dependency on evironmental parameters, operating conditions and supporting media. Journal of Environmental Management. v. 112, p. 429-448, 2012.

SCHEEREN, M. B.; KUNZ, A.; STEINMETZ, R. L. R.; DRESSTER, V. L. O processo ANAMMOX como alternativa para tratamento de águas residuárias, contendo altas concentrações de nitrogênio. Revista Brasileira de Engenharia Agrícola e Ambiental v. 15, n.12, p.1289-1297, 2011.

SEZERINO, P.H.; BENTO, A.P.; DECEZARO, S.T.; MAGRI, M.E.; PHILLIPPI, L.S. Experiências brasileiras com wetlands construídos aplicados ao tratamento de águas resíduárias: parâmetros de projeto para sistemas horizontais. Engenharia Sanitária e Ambiental. v. 20, n. 1, p. 151-158, 2015.

SOUSA, J. T.; van HAANDEL, A.; LIMA, E. P. C.; HENRIQUE, I. N. Utilização de wetland construído no pós-tratamento de esgotos domésticos pré-tratados em reator UASB. Revista Engenharia Sanitária e Ambiental, v. 9, n. 4, 285-290, 2004.

TONETTI, A.L.; CORAUCCI FILHO, B.; BERTONCINI, E.I.; OLIVEIRA, R.A.; STEFANUTTI, R.Avaliação de um sistema simplificado de tratamento de esgotos visando a utilização em áreas rurais. Revista Brasileira de Engenharia Agrícola e Ambiental, v. 14, n. 2, p. 227-234, 2010. 
UNITED STATES ENVIRONMENTAL PROTECTION AGENCY, USEPA. (1988). Design manual: constructed wetlands and aquatic plant systems for municipal wastewater treatment. Cincinnati, Ohio: Usepa, Office of Research and Development, (EPA/625/188/022).

VYMAZAL, J. Constructed Wetlands for Wastewater Treatment. Encyclopedia of Ecology (Second Edition), Volume 1, p. 14-21, 2019.

ZHANG, D.Q.; JINADASA, K.B.S.N, Gersberg, R.M., Liu, Y. Tan, S.K., Ng, W.J. Application of constructed wetlands for wastewater treatment in tropical and subtropical regions (2000-2013) Journal Environmental Science, v. 30, p. 30-46, 2015. 